\title{
The Perception of High School Communities towards River Restoration Program
}

\author{
Atie Tri Juniati ${ }^{1 *}$, Dwi Aryani ${ }^{1}$, Nuryani Tinumbia ${ }^{1}$, Fadli Kurnia ${ }^{1}$, \\ Atri Prautama Dewi ${ }^{2}$, Gatut Bayuaji ${ }^{3}, \mathrm{Hera}^{3}$, Nono Carsono ${ }^{4}$ \\ ${ }^{1}$ Civil Engineering Study Program, Faculty of Engineering, Universitas Pancasila, Jakarta Selatan, Indonesia \\ ${ }^{2}$ Architecture Study Program, Faculty of Engineering, Universitas Pancasila, Jakarta Selatan, Indonesia \\ ${ }^{3}$ Balai Besar Wilayah Sungai Cimanuk Cisanggarung (BBWS Cimancis), Cirebon, Indonesia \\ ${ }^{4}$ Civil Engineering Study Program, Sekolah Tinggi Teknologi Cirebon, Indonesia
}

Submitted: September 26 th 2019; Revised: June 13 th 2021; Accepted: September 20 th 2021

\begin{abstract}
Keywords: SDGs

Abstract River restoration is an activity to restore the river's condition to its

River restoration original state. River restoration is one of the SDGs, namely target 6.6, Aquatic

Balai besar Ecosystems. The target of $6.6 \mathrm{SDG}$ is to conserve and restore water-related ecosystems such as mountains, forests, wetland vegetation, rivers, reservoirs wilayah sungai and lakes. These SDGs will be successful with the participation of the surrounding community. In order to pursue this target, the Civil Engineering Study Program, Pancasila University has organized a community service program related to river restoration activities, in the Cimanuk-Cisanggarung river area, Cirebon. Community service activities are carried out by providing counseling about the importance of river restoration programs to high school teachers and assessing school readiness to form a water quality monitoring school partnership. To assess the understanding of river restoration and the readiness to establish partnership, a questionnaire was given. Based on the questionnaire analysis, it can be concluded that most of the participants (76\%) stated that the river restoration program was important and would be ready to partner with other schools (24\%). This shows that program respondents are ready to form partnerships to support river restoration programs.
\end{abstract}

\section{INTRODUCTION}

The entire goal of MDGs is meant to emphasize that human has the rights to get clean water, safe sanitation, cleanliness enhancement, as well as adequate, safe, affordable, and nutritious food. The world is a habitat where human can live safely and access the available sustainable energy (UN, 2015). Achieving the ambitious goals of Sustainable Development agenda would require a significant amount of effort and it cannot be done properly without the participation of the community.

River restoration is a movement that aims to restore a river to its natural state. This movement is one of SDGs, specifically target number 6.6, which is Aquatic Ecosystems. It includes protecting and restoring water-related ecosystems, such as mountains, forests, wetlands, rivers, aquifers, and lakes. The community participation is necessary in order to pursue the target. River restoration is related to flood prevention, or it can also be said that river restoration is a flood prevention measure. A successful river restoration will boost the recreational and aesthetic values in urban areas. The community participation is essential for river restoration program.

The number of river restoration programs keeps increasing the past few years. It involves various stakeholder groups, which frequently become the source of conflict of interest (Symmank et al., 2021). Community and stakeholders participations in river and watershed nature resource management is increasingly being promoted since it is expected to improve natural resource management and enable communities to engage freely and fairly in management (Carr, 2015). Raising the involvement of the community can be 
accomplished through cognitive enhancement, which includes increasing the knowledge about recycling, waste management, and the benefits of river restoration. However, this community participation process will fail if the quality of consultation with the stakeholders is poor, the access to the information is lacking, and public involvement in the planning is limited (Sobowale, 2019).

As a response to this river restoration program, people who concerns about river damage have begun to make efforts to improve river conditions by carrying out various movements (Kuncoro, 2018b; Maryono \& Members, 2016; Suaidi, 2018; Suharko \& Kusumadewi, 2019). One of them is Indonesia's River Restoration Movement (Gerakan Restorasi Sungai Indonesia or GRSI), which was originally established in Yogyakarta in 2014 and has expanded to several regions around Indonesia (Maryono \& Members, 2016). The movement is conducted using Networking, Community, and knowledge-based approach. This movement is also accompanied by Indonesia's River Restoration Movement (Gerakan Sekolah Sungai Indonesia or GSSI) for the learning process in creating and implementing systematic river restoration.

Some of river awareness movements which are currently conducted include the community participation in river preservation (Fadjarajani et al., 2018; Muktiali, 2018; Suharko \& Kusumadewi, 2019), a community participation movement for conservation (Setyowati et al., 2018), a research on the influence of community activities and behavior on river water quality (Council \& Zahra, 2019; Kospa \& Rahmadi, 2019; Sari et al., 2019; Yulistia, 2020), and monitoring river pollution (Ogston et al., 2018).

The government and the university support those community movements (Burrows et al., 2018; Herawati et al., 2019; Kuncoro, 2018b; Michelle Molina et al., 2016; Rachman, 2018) by providing counseling, training, on-site practice, arranging curriculum, and providing modules that are required based on the problems that have arisen (Michelle Molina et al., 2016).

The Student Creativity Program - Regional Partnership Program conducted by Civil Engineering Study Program, Faculty of Engineering, Pancasila University, as part of the Regional Partnership Program of Community Service, aims to enhance knowledge and raise people's awareness of their surroundings. Moreover, it can support the government's program, specifically the river restoration, which is currently implemented by the Cimanuk-Cisanggarung River Basin Center. Besides supporting the river restoration movement, this program will establish good ties between Pancasila University, the government (Cimanuk-Cisanggarung River Basin Center), and a local university named the University of Technology Cirebon.

Since the beginning of 2017, Cimanuk Cisanggarung River Basin Center has launched a river restoration program. The river restoration program planned by Cimanuk Cisanggarung River Basin Center was initiated due to the river problems and conditions in Cimanuk-Cisanggarung river area, such as the poor water quality in some water sources, which is indicated by COD, BOD (PO4), and Chloride $(\mathrm{Cl})$ parameters that exceed the quality standard. This condition happens because almost all of the river streams are contaminated with sulfate (SO4), sulfide (H2S), iron $(\mathrm{Fe})$, manganese $(\mathrm{Mn})$, and zinc $(\mathrm{Zn})$. Meanwhile, the BOD, COD, turbidity, ammonia, ammonium, nitrate, ortho phosphate, and fecal coliform parameters has exceeded B, C, D quality standards (Setyowati et al., 2018)

According to the Decree of the Governor of West Java Number 58 of 1998 on Water Allocation and Water Quality Standards, water that meets the allocation $\mathrm{B}$ is water for drinking, class $\mathrm{C}$ water is for fishery and livestock purposes, while class D water is water used for agriculture and can be used for urban enterprises, industry, and hydroelectric power generation.

Besides water quality issues, the CimanukCisanggarung river also faces another issues related to water quantity, which is indicated by heavier flood stream in the river that causes several critical river locations, such as damaged embankments and erosion or landslides at the river cliffs (Kuncoro, 2018a).

Cimancis River Basin Center needs community participation to implement the river restoration program. There are currently ten river awareness communities that have joined, consisting of elementary, middle school, high school, college students, heads of sub-district, state-owned enterprises, working communities, environmental awareness communities, housewives, and clerics or mosque communities. However, there is no coordinated and integrated river water quality monitoring program carried out by high school students. Therefore, the Faculty of Engineering from Pancasila University (FTUP) proposed a High School partnership program in filling out the MoU between the Faculty of Engineering from Pancasila University and Cimancis River Basin Center to support the river restoration program.

A proposed plan to establish Water Quality Monitoring School Partnership of Cimanuk Cisanggarung River was preceded by research on the condition of the school. A research was conducted to discover the school community's understanding of river 


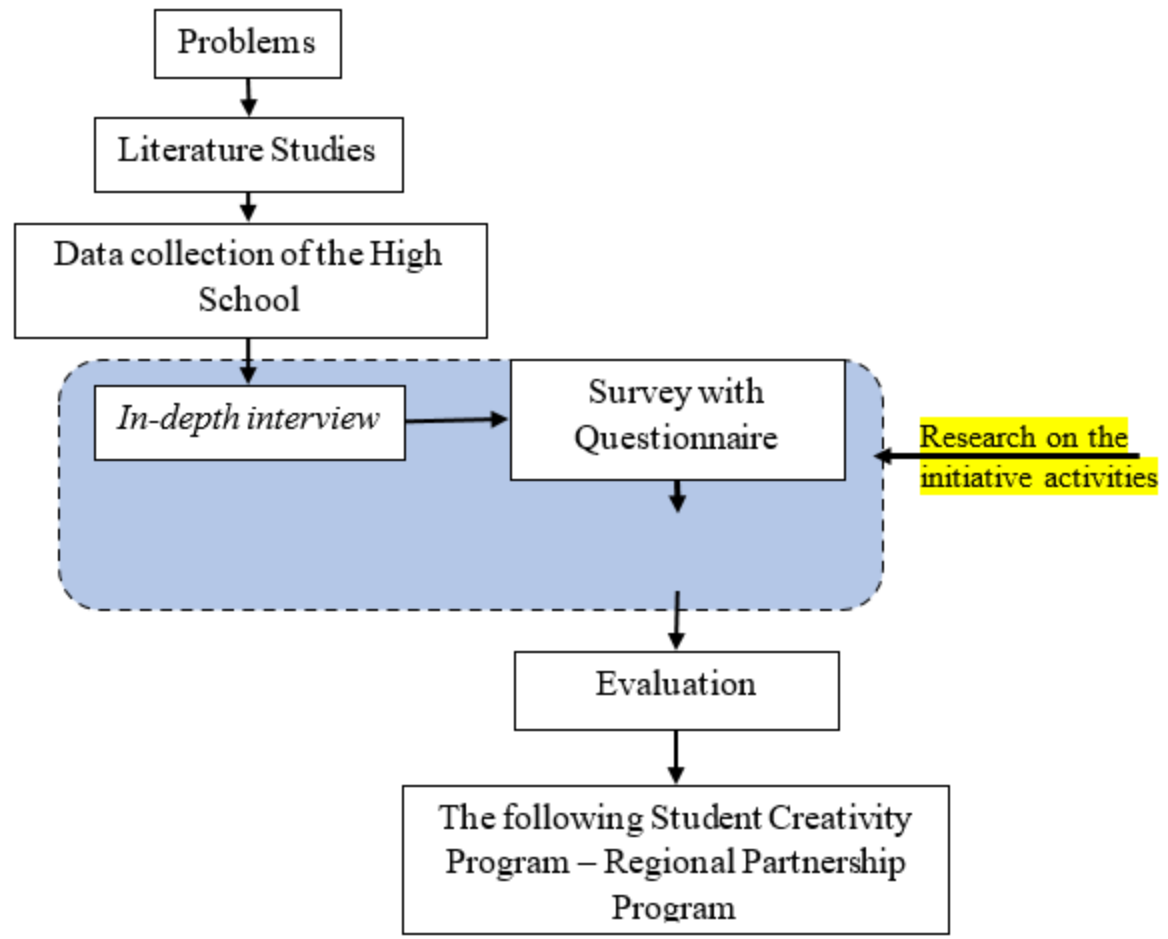

Figure 1. Research stages

restoration, as well as their readiness and willingness to establish a school partnership to support the river restoration program. Furthermore, it also aims to ascertain their concern towards an environment.

\section{METHOD}

This research aims to discover respondents' level of perception (high school teachers) who attended the Training of Trainer (ToT) about river restoration, as well as their readiness and willingness to establish school partnerships to support river restoration program. The research type is descriptive, with survey and interviews as the research techniques. It was conducted through the stages as follows:

\subsection{Data Collection}

The data collection techniques of quantitative research can be done through interviews, questionnaires, and observation (Sugiyono, 2010). This research employs primary data. The primary data are obtained from survey and observation in the field using two methods. The first method was in-depth interview combined with a group discussion. The second method was conducting a survey using a research instrument (questionnaire) with Likert scale and multiple choices.

\subsection{Questionnaire}

Sugiyono (2014) defines questionnaire as a data collection technique conducted by giving a set of questions or written statements for the respondents to be answered. The questionnaire can be in the form of closed or open questions or statements. The questionnaire employed in this research is the closed questionnaire, where the statements are used to discover teachers' perceptions about river restoration program and the readiness to establish school partnerships.

By employing Likert scale, the variables that will be measured are elaborated into variable indicators, in which these variables are used as the starting points to construct instrument items in the form of statements.

The response from each instrument item that employed Likert scale ranges from very positive to negative. For quantitative analysis purpose, the answers are then scored as follows:

$\begin{array}{ll}\text { Very important } & =3 \\ \text { Important } & =2 \\ \text { Less important } & =1 \\ \text { No opinion } & =0\end{array}$

Meanwhile, questionnaire is meant to indicate the understanding level of the respondents about river restoration. The variables and indicators measured in the research instrument are as Table 1.

\subsection{Documentation}

The documentation method in this research is used to collect data on the number and the names of high school teachers in the Cimanuk-Cisanggarung river area, photos of research activities, and the recorded interviews.

\subsection{Interviews}

The interview technique used in this research is unstructured interview. Sugiyono (2014) defines an unstructured interview as a free interview conducted without using interview guidelines that are arranged systematically and comprehensively. An interview is used to conduct an initiative study in acquiring the information needed for the research. In this case, the researcher interviewed the respondents and combined it 


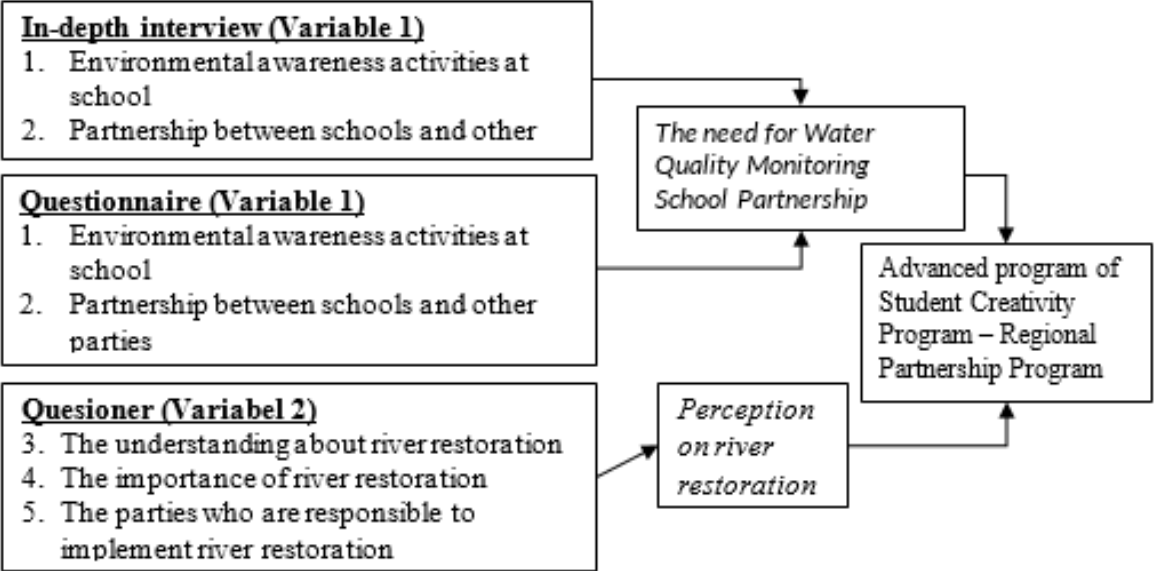

Figure 2. Data analysis

with a group discussion. Interviews/In depth interviews are intended to find out the opinion of respondents about the importance of environmental awareness programs and school partnerships, as well as clarification of the answers to the questionnaire.

\subsection{Data Analysis}

\subsubsection{Environmental awareness activities}

The type of the research is descriptive and the technique is survey and interview. The research took place in Darma Kuningan Reservoir, Kuningan, West Java. The counseling, as a part of the research, was given to twenty teachers from ten High Schools as the beginner group, followed by the counseling for forty teachers from twenty Senior High Schools. The first activity was held in Darma Kuningan Reservoir, from 19 to 20 September, 2018.

The activity in Darma Kuningan Reservoir, was attended by the teachers from Senior High Schools and Vocational High Schools located along Cimanuk and Cisanggarung river, namely Cirebon State High School, Mundu State Vocational High School, Ciledug State Senior High School, Muhammadiyah Kedawung Vocational High School, Kadugede State Senior High School, and Beber State Senior High School. Each school sent two teachers, consisting of one male teacher and one female teacher who teach physics, chemistry, biology, and geography. The second ToT, which was held drom 19 to 20 September, 2018 at the hall of Cimanuk-Cisanggarung River Basin Center, was attended by thirty teachers from eighteen Senior High Schools.

The data that will be analyzed were collected using questionnaires and interviews (in-depth interviews) with the teacher. The data were descriptively analyzed to learn about the opinion of High School communities in Cimanuk-Cisanggarung river area towards the river restoration movement and the significance of partnership establishment. The results of the data analysis provide significant information to plan the next action, as shown in the diagram below.

\subsubsection{School community awareness for regional partnership program}

The level of perception of the school community towards the river restoration program in this study was assessed based on the opinion scores of the respondents or high school teachers in Cimanuk-Cisanggarung river area. The data obtained from the results of the questionnaire distribution are presented in tabulated form. Then, the percentage calculation is done using the formula as follows (Sudijono, 2011):

$$
P(\%)=\frac{n_{i}}{N} \times 100 \%
$$

where:

$$
\begin{aligned}
& P=\text { percentage of the perception } \\
& n_{i}=\text { the number of samples in category } i \\
& i=\text { high, medium, and low category } \\
& N=\text { total sample }
\end{aligned}
$$

Based on the data calculation above, the data were analysed descriptively to obtain an overview of teachers' perceptions towards river restoration and school partnerships.

\section{RESULT AND DISCUSSION}

\subsection{Teacher's understanding or perception towards river restoration}

The perceptions of the teachers participating in the counseling towards river restoration program and the existence of environmental awareness programs in respective school can be seen in the diagrams below.

The results of the questionnaire analysis of 23 respondents shows that $14 \%$ of the respondents knew about river restoration, $70 \%$ had heard of it, and $12 \%$ did not know about it. It indicates that only partially of the teacher did not know about it. It indicates that only partially of the teachers know about river restoration paradigm and activities. Therefore, the similar counseling activities need to be conveyed to the school community in particular and the wider community in general, so that the level of community awareness towards the river will increase even more. This is in line with the respondents' perceptions as shown in Figure 3.b. 


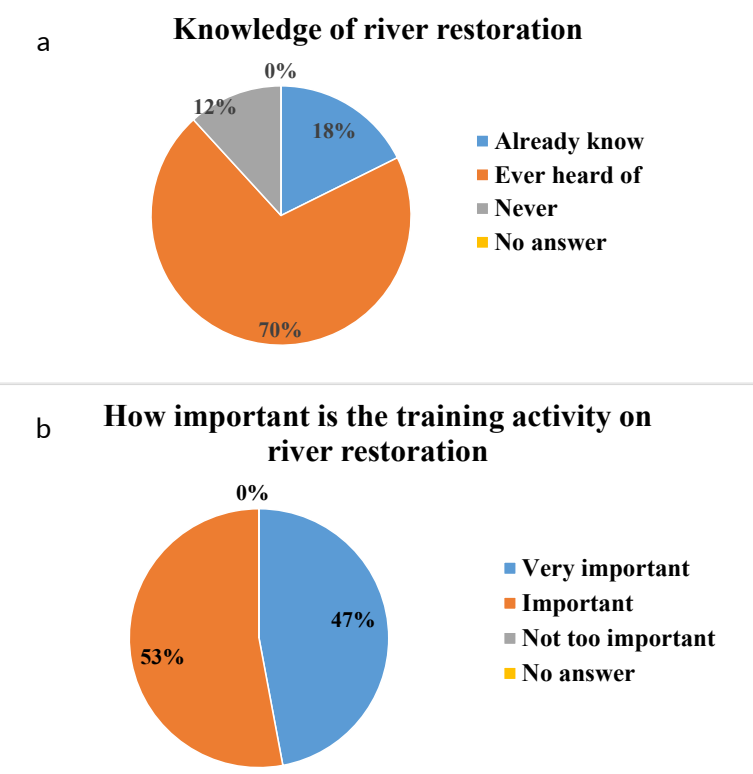

Figure 3. The percentage of the respondents' responses about a) The understanding of river restoration; b) The level of importance of river restoration counseling

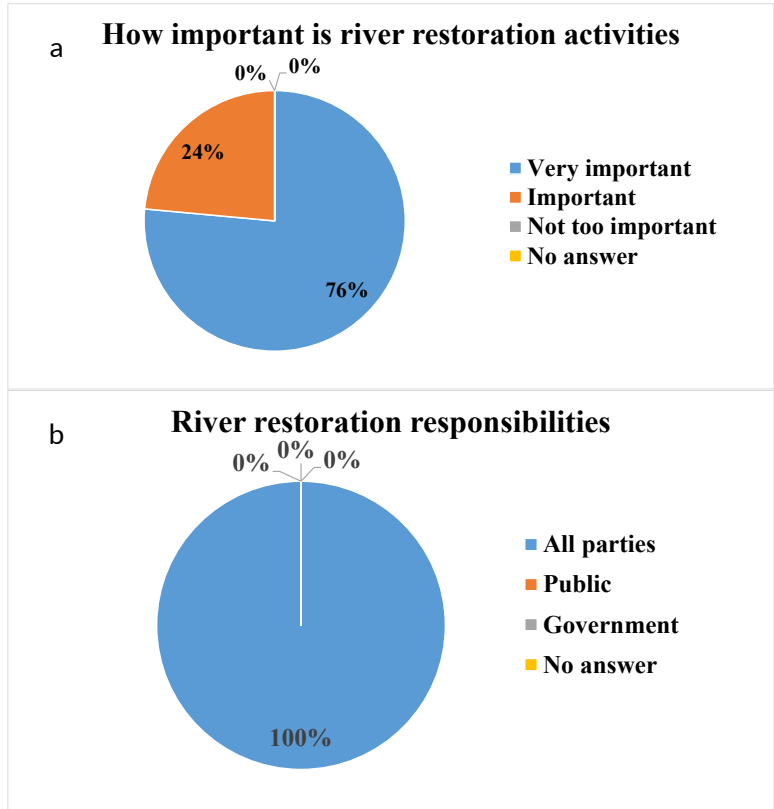

Figure 4. The respondents' perceptions towards river restoration program

The majority of the respondents $(76 \%)$ agreed that this river restoration activity is very important, followed by $24 \%$ respondents who stated that it is important (Figure 4.a). Furthermore, all participants agreed that river restoration activity is the responsibility of all parties, not only the community or the government (Figure 4.b).

Figure 5 shows that $41 \%$ of the respondents stated that there were already environmental awareness programs in their schools, most of which were student extracurricular activities that had not been started long ago (started in 2011 at the latest). Furthermore, only a small percentage of the respondents $(12 \%)$ claimed that the environmental awareness program in their respective schools had collaborated with other schools (extracurricular activities of other schools). This illustrates the need to increase similar activities to increase awareness of environment, especially rivers.

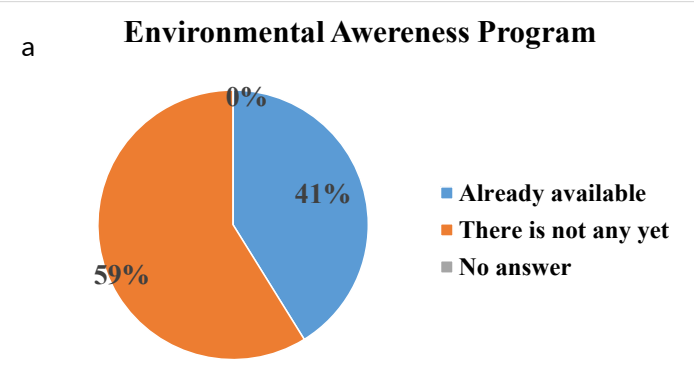

b The existence of partnerships with other parties

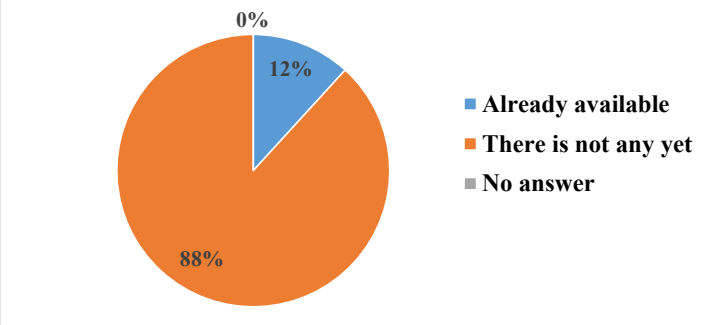

c There are partnerships with other schools

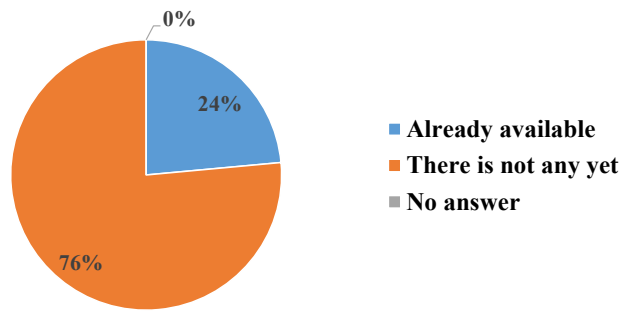

Figure 5. a) The existence of environmental awareness program in school; b) Partnership with other parties; c) Partnership with other schools

\section{CONCLUSION}

Based on the questionnaire analysis and group discussions, it can be concluded that the respondents' perceptions of the river restoration movement are very good. This can be seen from the majority of respondents (76\%) who agree that river restoration activities are very important. The school is also ready to build a Water Quality Monitoring School Partnership to support the Cimanuk-Cisangagrung river restoration program. This can be seen from several schools that have experience in environmental collaboration with the surrounding community $(12 \%)$ and other schools (24\%). Thus, the school partnership program is likely to be successful.

\section{ACKNOWLEDGMENT}

This research is funded by The Ministry of Research and Higher Education Grand PPM-PKW 2019 with the Decree Number 03/AKM/P2M/2019 through a contract letter with the Research and Community Service Board of Pancasila University Number 3598/LPPM/UP/V/2019. 


\section{REFERENCES}

Burrows, A., Lockwood, M., Borowczak, M., Janak, E., \& Barber, B. (2018). Integrated STEM: Focus on informal education and community collaboration through engineering. Education Sciences, 8(1). DOI: https://doi.org/10.3390/educsci8010004

Carr, G. (2015). Stakeholder and public participation in river basin management - an introduction. WIREs Water, 2(4), 393-405. DOI: https://doi.org/10.1002/wat2.1086

Council, S., \& Zahra, I. (2019). Padjadjaran Law Review Padjadjaran Law Review. 7, 71-83.

Fadjarajani, S., Singkawijaya, E. B., \& Indriane, T. (2018). Peran Serta Masyarakat Dalam Menjaga Kelestarian Sungai Cimulu di Kota Tasikmalaya. Prosiding Seminar Nasional Geografi UMS IX 2018. Restorasi Sungai: Tantangan Dan Solusi Pembangunan Berkelanjutan, 2000, 248-254.

Herawati, H., Kurniawati, N., Maulina, I., Hasan, Z., Sahidin, A., Apriliani, I. M., \& Dewanti, L. P. (2019). Penyuluhan Pemilahan Sampah Domestik Sebagai Peningkatan Kesadaran Siswa dalam Usaha Menjaga Kualitas Air Waduk Jatigede di SMP Negeri 2 Darmaraja Kabupaten Sumedang. Dharmakarya: Jurnal Aplikasi Ipteks Untuk Masyarakat, 8(2), 111-114.

Kospa, H. S. D., \& Rahmadi, R. (2019). Pengaruh Perilaku Masyarakat Terhadap Kualitas Air di Sungai Sekanak Kota Palembang. Jurnal Ilmu Lingkungan, $\quad 17(2), \quad 212 . \quad$ DOI: https://doi.org/10.14710/jil.17.2.212-221

Kuncoro, D. A. (2018a). Penerapan Bio · Engineering Dan Sistem Urug Perkuatan Wadah Generik (SUPWG) Berwawasan Lingkungan Dalam Rangka Restorasi Sungai di Wilayah Sungai Cimanuk - Cisanggarung. Prosiding Seminar Nasional Geografi UMS IX 2018. Restorasi Sungai: Tantangan Dan Solusi Pembangunan Berkelanjutan, 1-18.

Kuncoro, D. A. (2018b). Penerapan Mobil Literasi Sungai Dalam Mendukung Restorasi Sungai. Prosiding Seminar Nasional Geografi UMS IX 2018 Restorasi Sungai: Tantangan Dan Solusi Pembangunan Berkelanjutan, 371-378.

Maryono, A., \& Members, G. N. (2016). Gerakan Restorasi Sungai Indonesia dan Gerakan Sekolah Indonesia untuk GNKPA. Paparan pada Dialog Nasional GNKPA, 14 November 2016, Jakarta. Asdak, C. (2002). Hidrologi dan pengelolaan daerah aliran sungai. Ga.

Michelle Molina, Erica Watson-Currie, \& Lauren B. Birney. (2016). Development of Curriculum + Community Enterprise for Restoration Science: A Formative Model for Educational Partnerships. Journal of Psychology Research, 6(8), 466-472. DOI: https://doi.org/10.17265/21595542/2016.08.004

Muktiali, M. (2018). Pemberdayaan / Partisipasi Masyarakat Dalam Restorasi Sungai Di Das Hulu Bengawan Solo. Kabupaten Wonogiri.
Prosiding Seminar Nasional Geografi UMS IX 2018 Restorasi Sungai: Tantangan Dan Solusi Pembangunan Berkelanjutan, 316-321.

Ogston, A., Miller, I. M., Dawson, C., \& Elder, N. (2018). Experiential education and outreach based on nearshore monitoring of the Elwha River restoration project. Salish Sea Ecosystem Conference.

Rachman, L. M. (2018). Potensi, Peran, dan Kontribusi Perguruan Tinggi dalam Restorasi Sungai. Prosiding Seminar Nasional Geografi UMS IX 2018 Restorasi Sungai: Tantangan Dan Solusi Pembangunan Berkelanjutan, 379-391.

Sari, I. N., Studi, P., Geografi, P., \& Keguruan, F. (2019). Terhadap Kualitas Air Sungai Banjaran Kabupaten Banyumas. Prosiding Seminar Nasional Diselenggarakan Pendidikan Geografi FKIP UMP "Manajemen Bencana Di Era Revolusi Industri 5.0," 82, 315-323.

Setyowati, D. L., Hardati, P., \& Arsal, T. (2018). Konservasi Sungai Berbasis Masyarakat di Desa Lerep DAS Garang Hulu. Prosiding Seminar Nasional Geografi UMS IX 2018, 401-410.

Sobowale, O. R. (2019). River Restoration in Nairobi, Kenya: Exploring Public Participation and Learning Outcomes. University Of Manitoba. Winnipeg.

Suaidi, I. (2018). Upaya Go River Indonesia dalam meningkatkan Kesadaran Masyarakat Peduli Lingkungan Sungai Deli di Kelurahan Sukaraja Kecamatan Medan Maimun. Universitas islam Negeri Sumatra Utara.

Sudijono, A. (2011). Pengantar Statistik Pendidikan. Rajawali Press.

Sugiyono. (2010). Metode Penelitian Kuantitatif Kualitatif dan R\&D (11th ed.). CV Alfabeta.

Suharko, S., \& Kusumadewi, C. D. M. (2019). Organisasi Masyarakat Sipil dan Restorasi Sungai: Studi pada Gerakan Memungut Sehelai Sampah di Sungai Karang Mumus di Kota Samarinda. Jurnal Sosiologi Reflektif, 14(1), 81. DOI: https://doi.org/10.14421/jsr.v14i1.1677

Symmank, L., Profeta, A., \& Niens, C. (2021). Valuation of river restoration measures-Do residential preferences depend on leisure behaviour? European Planning Studies, 29(3), 580-600.

DOI: https://doi.org/10.1080/09654313.2020.176079 2

UN. (2015). Transforming our world: The 2030 agenda for sustainable development. In sustainabledevelopment.un.org (Issue 1). DOI: https://doi.org/10.1007/s13398-014-0173-7.2

Yulistia, E. (2020). Dampak Kegiatan Masyarakat di Sempadan Sungai Terhadap Kualitas Air Sungai Ogan di Kota Baturaja Kabupaten OKU Effects of Society Activities in Riparian Area of Ogan River in Baturaja City Kabupaten OKU. 01(01). 